Provided for non-commercial research and education use. Not for reproduction, distribution or commercial use.

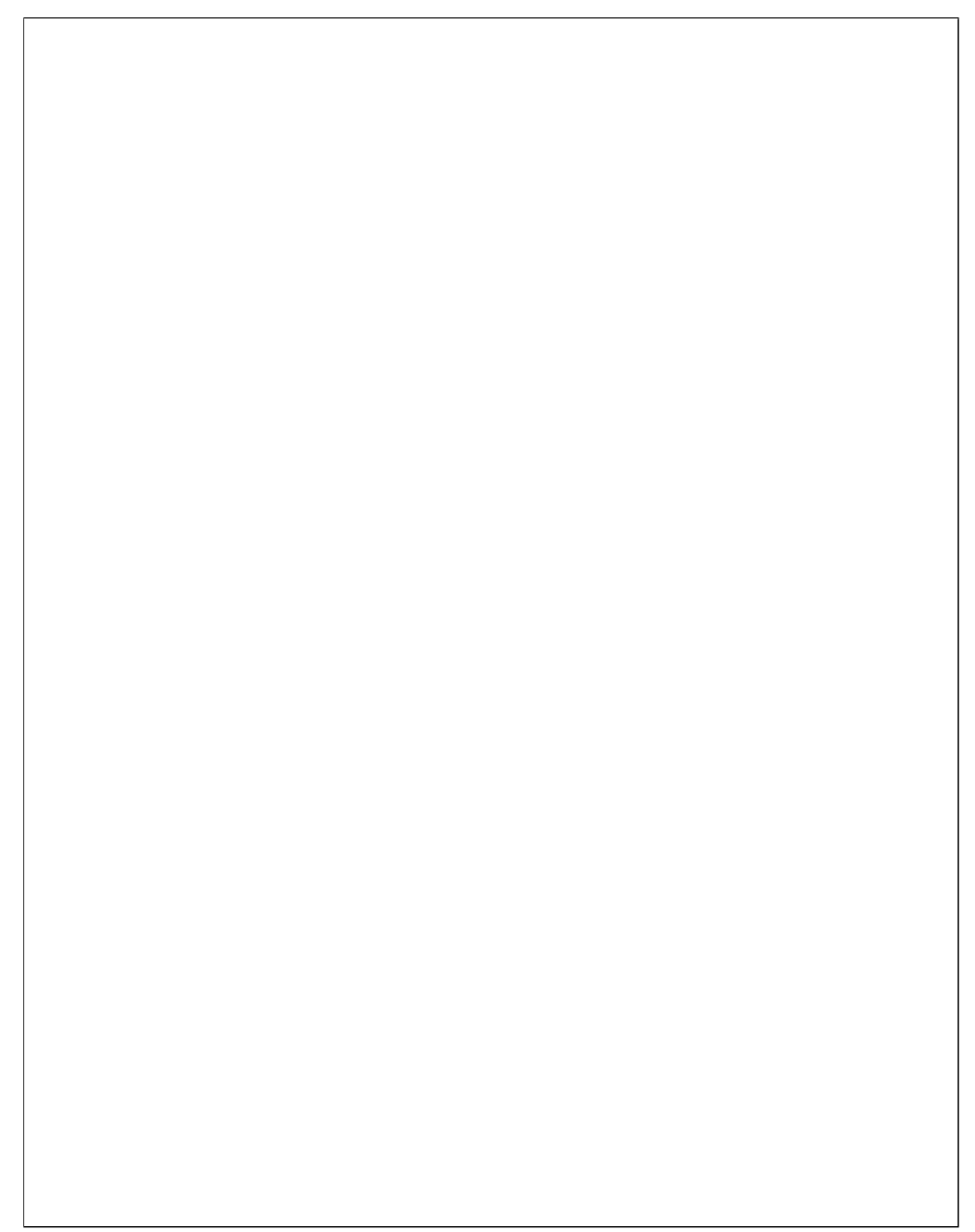

This article appeared in a journal published by Elsevier. The attached copy is furnished to the author for internal non-commercial research and education use, including for instruction at the authors institution and sharing with colleagues.

Other uses, including reproduction and distribution, or selling or licensing copies, or posting to personal, institutional or third party websites are prohibited.

In most cases authors are permitted to post their version of the article (e.g. in Word or Tex form) to their personal website or institutional repository. Authors requiring further information regarding Elsevier's archiving and manuscript policies are encouraged to visit:

http://www.elsevier.com/copyright 


\title{
Dramatically different levels of cacna1a gene expression between pre-weaning wild type and leaner mice
}

\author{
Liana Veneziano a $^{\text {, }}$ Serena Albertosi ${ }^{\text {b }}$, Daniela Pesci ${ }^{\mathrm{b}}$, Elide Mantuano ${ }^{\mathrm{a}}$, Marina Frontali ${ }^{\mathrm{a}}$, Carla Jodice ${ }^{\mathrm{b}, \mathrm{c}, *}$ \\ a Istituto di Farmacologia Traslazionale, CNR, Via Fosso del Cavaliere, 00133 Roma, Italy \\ b Dipartimento di Biologia, Università Tor Vergata, Via della Ricerca Scientifica, Roma, Italy \\ c CIMN Inter-University Research Centre on the Molecular Basis of Neurodegenerative Diseases, Italy
}

\section{A R T I C L E I N F O}

\section{Article history:}

Received 9 December 2010

Received in revised form 28 February 2011

Accepted 3 March 2011

Available online 26 March 2011

\section{Keywords:}

Episodic ataxia type 2

Voltage gated calcium channel

EA2 truncating mutations

Haploinsufficiency

Nonsense mediated decay

Autosomal dominant cerebellar ataxia

ADCA

\begin{abstract}
A B S T R A C T
Loss of function mutations of the CACNA1A gene, coding for the $\alpha 1 \mathrm{~A}$ subunit of $\mathrm{P} / \mathrm{Q}$ type voltage-gated calcium channel $\left(\mathrm{Ca}_{\mathrm{V}} 2.1\right)$, are responsible for Episodic Ataxia type 2 (EA2), an autosomal dominant disorder. A dominant negative effect of the EA2 mutated protein, rather than a haploinsufficiency mechanism, has been hypothesised both for protein-truncating and missense mutations. We analysed the cacna1a mRNA expression in leaner mice carrying a cacna1a mutation leading to a premature stop codon. The results showed a very low mutant mRNA expression compared to the wild type allele. Although the mutant mRNA slightly increases with age, its low level is likely due to degradation by nonsense mediated decay, a quality control mechanism that selectively degrades mRNA harbouring premature stop codons. These data have implications for EA2 in humans, suggesting a haploinsufficiency mechanism at least for some of the CACNA1A mutations leading to a premature stop codon.
\end{abstract}

(c) 2011 Elsevier B.V. All rights reserved.

\section{Introduction}

The human CACNA1A gene on chromosome 19p13 encodes the $\alpha_{1 \mathrm{~A}}$ pore-forming subunit of $\mathrm{P} / \mathrm{Q}$ type voltage-gated $\mathrm{Ca}^{2+}$ channel $\left(\mathrm{Ca}_{\mathrm{v}} 2.1\right)$. The protein has a tissue specific expression in neurons, particularly in cerebellar Purkinje and granule cells, as well as in neuromuscular junctions [1-3]. Mutations of the CACNA1A gene leading to a complete or a partial impairment of $\mathrm{Ca}^{2+}$ influx [4-8] are responsible for Episodic Ataxia type 2 (EA2, OMIM 108500). EA2 is an early onset, autosomal dominant disorder characterised by attacks of vertigo/ataxia, visual disturbance, dysarthria, interictal cerebellar deficit of extremely variable severity, and cerebellar atrophy; epilepsy has occasionally been described $[9,10]$. A dominant negative effect of the $\mathrm{Ca}_{\mathrm{v}} 2.1$ mutated protein affecting the wild type product, rather than a haploinsufficiency, has been hypothesised [6,11-14].

Loss of function mutations of the mouse orthologue of the CACNA1A gene cause recessive neurological phenotypes, in tottering (cacna1ats; tg), leaner (cacna1a $a^{\text {tg-la }}$ tg-la), rocker (cacna1 $\left.{ }^{r k r}\right)$ and

Abbreviations: CACNA1A, gene encoding $\mathrm{P} / \mathrm{Q}$ type $\alpha_{1} \mathrm{~A}$ subunit voltage-dependent calcium channel; $\mathrm{Ca}_{\mathrm{V}} 2.1, \alpha_{1} \mathrm{~A}$ subunit of $\mathrm{P} / \mathrm{Q}$ voltage-dependent calcium channel; EA2, Episodic Ataxia type 2; tg, tottering; tg-la, leaner; rkr, rocker; rolling-nagoya, tg-rol; PTC, premature translation termination codon; NMD, nonsense-mediated decay; qRT-PCR, Quantitative Real-Time PCR; ANOVA, Analysis of variance; RQ, Relative Quantity.

* Corresponding author at: Dipartimento di Biologia, Università Tor Vergata, Via della Ricerca Scientifica, Roma Italy. Tel.: +39 0672594321; fax: +39062023500.

E-mail address: carla.jodice@uniroma2.it (C. Jodice). rolling Nagoya (cacna1a ${ }^{\text {tg-rol }}$ ) mice [15,16]. In addition, one dominant cacna1a mutation was recently described in the wobbly mouse [17]. Homozygous mice for leaner, tottering and rocker mutations are all affected by a more or less severe form of ataxia and absence epilepsy. Leaner mice show the most severe ataxic phenotype with extensive degeneration of Purkinje cells and cerebellar granules. Tottering, rocker, rolling Nagoya and wobbly phenotypes are all caused by point mutations resulting in an amino acid exchange (P601L, T1310K, R1262G and R1255L, respectively), while leaner is due to a mutation causing an aberrant splice and a premature translation termination codon (PTC), thus producing a truncated protein.

Besides the protein truncation, the PTC makes the mutated mRNA a good candidate for the quality control mechanism of nonsensemediated decay (NMD), that selectively degrades mRNA harbouring PTC [reviewed in 18,19]. Should this be the case, a reduced expression of the mutant gene would be expected in leaner mice.

A solid support to this hypothesis comes from mice carrying null or knockout cacna1a mutations. Their phenotype overlaps that of leaner mice, suggesting a strongly reduced or complete absence of the gene product in these mice as well [20,21]. Moreover, mice with knockdown mutations develop ataxia and cerebellar atrophy, with a severity of symptoms and a rate of progression inversely correlated with the amount of expressed $\mathrm{Ca}_{\mathrm{V}} 2.1$ [22].

The hypothesis that cacna1a mutations leading to PTC are subject to NMD also has implications for human EA2 mutations of the same kind, accounting for more than $60 \%$ of the total [10]. If mRNA turns out 
to be degraded, no truncated protein will be present, thus indicating a haploinsufficiency mechanism rather than a dominant negative effect.

We have analysed the expression of cacna1a mRNA in brains of wild type and heterozygous and homozygous leaner pre-weaning mice. The results show a dramatic decrease of the cacna1 $a^{\text {tg-la }}$ allele expression, compared to the wild-type allele, in the heterozygous and in the homozygous mutant mice, as well as a variable expression of mutant and wild-type cacna1a related to age.

\section{Materials and methods}

\subsection{Animals}

Experiments were performed on pre-weaning and adult mice. The C57BL/6-congenic leaner mutant strain with an oligosyndactylism marker gene $\left(O s+/+\right.$ cacna1 $\left.a^{\text {tg-la }}\right)$ was obtained from Jackson Laboratory (USA). Leaner homozygous mice were obtained by intercross-

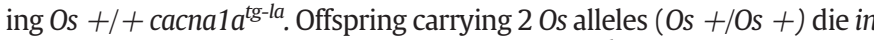
utero [23]; those genotypically Os $+1+$ cacna1 $^{\text {tg-la }}{ }^{\text {offspring have fused }}$ digits due to the $O$ s allele; therefore, surviving offspring with normal digits were identified as leaner homozygous ( + cacna1 $a^{\text {tg-la }} /+$ cacna $\left.1 a^{\text {tg-la }}\right)$. In addition the genotypes of all mice here studied were confirmed by sequence analysis of genomic DNA.

\section{2. cDNA amplification}

Total brain RNA was isolated from homozygous and heterozygous leaner mice and wild type mice using Trizol ${ }^{\circledR}$ Reagent (Invitrogen) following the manufacturer's protocols. After isolation, RNA preparations were digested with DNasel. cDNAs were synthesised from $4 \mu \mathrm{g}$ of total RNA in $25 \mu \mathrm{l}$ of volume using random hexamers with GeneAmp RNA PCR Kit Applied Biosystems N808-0143.

\subsection{Semi-quantitative $P C R$}

Two $\mu$ of the reverse transcription mix was amplified by PCR in the presence of ${ }^{32} \mathrm{P} \alpha$-dCTP using the following sets of primers: 1) 5'-AGC AAG AGA GGC ATC CTG ACC- $3^{\prime}$ and $5^{\prime}$-CTC ATT GCC GAT AGT GAT GAC C-3' for $\beta$-actin, used as internal control; 2) 5'-ACA GCC TTA TCG TCA CCA AC- $3^{\prime}$ and $5^{\prime}$-ATG AAC ATG GAG CTG TAG GG-3' for fragment 3140-3386 (Acc. no. MMU76716) of cacna1a, unmodified in the mutant; and 3) 5'-ACG AAG GCG GCA TGA AGG AG-3' and 5'-GAG GTA GTG TTC GCT GTC TG-3' for fragment 5771-5958 (Acc. no. MMU76716) of cacna1a, including the $98 \mathrm{nt}$ intron not spliced in the mutant form.

The PCR program was: 1 min at $94{ }^{\circ} \mathrm{C}, 1 \mathrm{~min}$ at $60^{\circ} \mathrm{C}$ (first 5 cycles) or $58^{\circ} \mathrm{C}$ (additional cycles) and $1 \mathrm{~min}$ at $72{ }^{\circ} \mathrm{C}$ for a total of 15 and 17 cycles. Preliminary experiments were done to determine the optimal number of cycles to ensure that the degree of amplification had a linear dependence on RNA concentration. Duplicate samples were analyzed.
Separation of the PCR products was performed on 6\% polyacrylamide gel (PAGE), vacuum dried for $30 \mathrm{~min}$ at $80^{\circ} \mathrm{C}$, exposed to phosphor screen overnight and acquired by PhosphorImager ${ }^{\mathrm{TM}}$ technology in a Storm 820 (GE Healthcare). Densitometric analysis was done using the ImageQuant (Molecular Dynamics, Sunnyvale, CA) software. The cacna1a mRNA expression was normalised over $\beta$-actin mRNA expression.

\subsection{Quantitative Real-Time PCR ( $q R T-P C R)$}

PCR amplification and detection were performed using ABI Prism 7000 Sequence Detection System (Applied Biosystems) in a final volume of $25 \mu \mathrm{l}$. All PCR reactions (three reactions for each sample) were replicated at least four times and contained $100 \mathrm{ng}$ of cDNA, $12.5 \mu \mathrm{l}$ of TaqMan Universal Master Mix (Applied Biosystems) including the passive reference ROX, $1.25 \mu \mathrm{l}$ of Assay on Demand Gene Expression Assay Mix for wild-type and mutated sequences (Applied Biosystems). The sequences of the PCR primers and probes (FAM dye labelled) are: 1 ) Forward: 5'-CCTAACAGCCAGCCCAACTC-3', Reverse: 5'-GGAGGTAGTGTTCGCTGTCTGA-3' and Probe: 5'-CAGTCTGTGGAGATGCGAGAAATGGGT-3' for wild type sequence assay; and 2) Forward: 5'-CCGCAGGCTGGGTGG-3', Reverse: 5'-GAGTCTGGAGTCTCTGTATGGGAGA-3' and Probe: 5'-TCAGGCAGAAAGGG-3' for mutated sequence assay.

Negative controls were also assayed. The PCR reaction was performed under the following conditions: $50^{\circ} \mathrm{C}$ for $2 \mathrm{~min}, 95^{\circ} \mathrm{C}$ for $10 \mathrm{~min}$ and 40 cycles $\left(95^{\circ}\right.$ for $15 \mathrm{~s}$ and $60^{\circ} \mathrm{C}$ for $1 \mathrm{~min}$ ). GAPDH amplification was used to normalise the reactions (TaqMan GAPDH Control Reagents Kit Applied Biosystems).

As the efficiencies of the endogenous control and target PCR reactions were equivalent, the relative RNA abundance (RQ) was calculated according to the "comparative $C_{T}$ method $\left(\Delta \Delta C_{T}\right.$ Method)" (available from http://www3.appliedbiosystems.com/cms/groups/ mcb_support/documents/generaldocuments/cms_042380.pdf), where the amount of target, normalized to an endogenous reference and relative to a calibrator, is given by: $2^{-\Delta \Delta C_{T}}$. The relative cumulative expression (Relative Expression) of cacna1a ${ }^{+}$and/or cacna1 $a^{\text {tg-la }}$ alleles for each homozygous or heterozygous mouse was calculated as the ratio of the summed $2^{-\Delta C_{T}}$ values of cacna1a ${ }^{+}$(WT) and cacna1atg-la $(\mathrm{LN})$ mRNAs and the minimal value of the sums (calibrator) observed across the entire series.

\section{Results}

The relative expression levels of cacna1a in whole brain were determined initially by semi-quantitative analysis. Fig. 1 shows representative PAGE of wild type, heterozygous and leaner mice semiquantitative radioactive PCRs used to measure the mRNA levels of the wild type and mutant cacna1a genes. In this case, $\beta$-actin was used as internal control and the relative expression was revealed by densitometry of the 245 bp band of fragment 3140-3386 present in

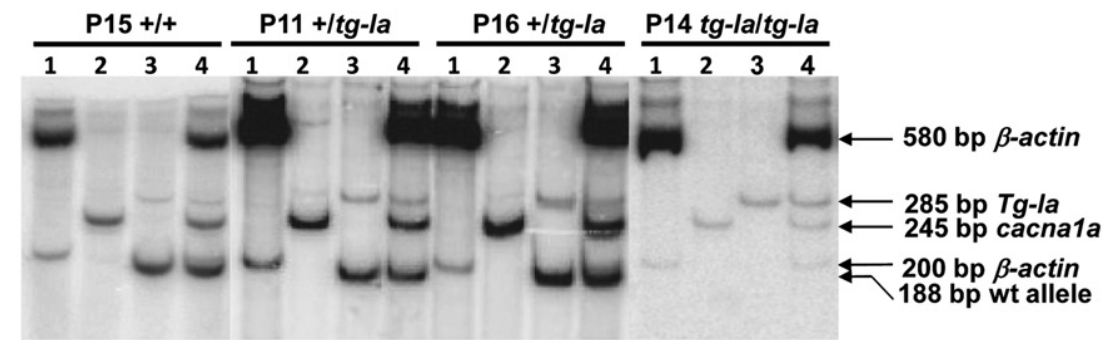

Fig. 1. Semiquantitative PCR analysis of normal $(+)$ and leaner (tg-la) cacna1a alleles in wild type (P15 +/+), heterozygous (P11 and P16 +/tg-la) and leaner (P14 tg-la/tg-la) mice. Four PCR reactions are shown for each mouse: 1 . $\beta$-actin; 2 . fragment 3140-3386 unvaried in normal and mutant allele, here named cacna1a; 3 . fragment 5771-5958 producing a 188 bp long band in normal allele and 285 bp if the intron has not been spliced; and 4 . multiplex with all 3 pairs of primers. Note that a minimal amount of the aberrant splicing product is present also in wild type samples, this producing even an overestimate of the mutant allele in heterozygotes. 
both alleles (data not shown). The mRNA expression of normal and Tg-la alleles showed a statistically significant difference among the three genotypes (Kruskal-Wallis 1-way ANOVA test; chi-square, 2 $\mathrm{df}=9.68 ; \mathrm{P}=0.0079$ ).

The relative expression levels of cacna1a mRNA in whole brain were then determined using the TaqMan qRT-PCR method, and were normalised against GADPH RNA as endogenous control. The results are presented as Relative Expression (see Materials and methods) of homozygous and heterozygous mice (Fig. 2A) or Relative Quantity (RQ) calculated by $2\left(-\right.$ Delta Delta $C(T)$ ) method [24] of cacna1a ${ }^{+}$vs cacna1a $a^{\text {tg-la }}$ in heterozygous mice (Fig. 2B). Each sample has been analysed at least four times and data reported in the graphics are expressed as the mean $\pm 2 \times$ SEM.

Fig. 2A shows the Relative Expression of total cacna1a mRNA of the three genotypes, wild type, heterozygote and leaner as a function of age. The total amount of mRNA in heterozygous mice has been obtained by summing the mRNA produced by cacna1a $a^{+}$and cacna1atg-la alleles. Irrespective of age, the Relative Expression data of the three groups, wild types, heterozygotes and leaner mice, have been compared by the nonparametric Kruskal-Wallis 1-way ANOVA test. Their difference turned out to be highly significant (chi-square, $2 \mathrm{df}=12.21 ; \mathrm{P}=0.0022$ ) (mean rank 14.29, 9.00 and 3.40 respectively). This was consistent with a decreased expression of the cacna1 $a^{\text {tg-la }}$ allele. In addition, the expression increases with age in all the three genotypes, but the slope is much lower in mutant homozygotes than in wild types (slope: 0.035 vs.0.142), and values observed at post-natal days 1-3 in the wild types are much higher than in the other homozygous genotype (y-intercept: 2.64 vs. 0.58). Linear regression analysis in heterozygotes has not been applied because of their heterogeneous age. Fig. 2B shows the

A
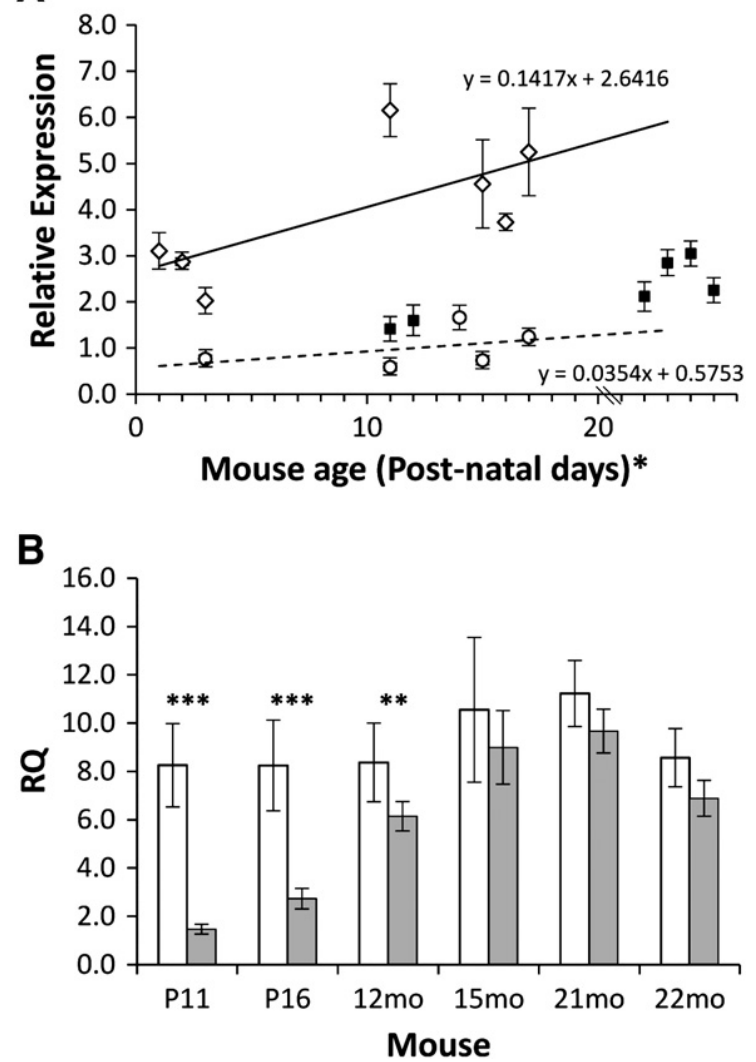

Fig. 2. A) Cacna1 a mRNA Relative Expression plotted against mouse age for wild types $(\diamond)$, heterozygotes $(\mathbf{\square})$ and leaner mice $(O) .{ }^{*}$ Heterozygous mice beyond age P20 are adults, aged 12, 15, 21 and 22 months, respectively. Trendlines and their equations are shown for wild types (solid line) and leaner mice (dotted line). B) Comparison between wild type (white bars) and leaner (grey bars) cacna1a allele mRNA Relative Quantity (RQ) in heterozygous mice. $\left({ }^{* * *} \mathrm{P} \ll 0.01 ;{ }^{* *} \mathrm{P}<0.05\right.$.) (Error bars $=2 \times \mathrm{SEM}$.) distribution of the RQs of cacna1a $a^{+}$and cacna1atg-la alleles in heterozygous mice. Pre-weaning mice (P11 and P16) and 12 month old mouse show significantly lower expression of the cacna1 $a^{\text {tg-la }}$ allele as compared to the normal one (Student's $t$-test; $\mathrm{P}=0,0005, \mathrm{P}=0,004$ and $\mathrm{P}=0.041$, respectively). On the other hand, in elder mice (21 and 22 months old), this difference is not maintained. However, it must be noted that these mice have a total amount of RNA which is about half of that of wild type animals (Fig. 2A), as expected in diploid genotypes expressing only one gene.

\section{Discussion}

Leaner mice are affected by a severe form of recessive ataxia with symptoms as early as 8-10 days of age. Most of these mice die by weaning. The disease is due to a splice mutation of the cacna1a gene, leading to a PTC and making the mRNA a possible candidate for degradation through NMD. Our results provide evidence of a very low level of mutant cacna1 $a^{\text {tg-la }}$ mRNA in the brain of pre-weaning leaner mice, suggesting that NMD control on this gene is active at the onset of the disease. In addition, the relative quantity of the mutant allele increases with age, as shown in heterozygous animals, reaching almost the same level of the wild type allele during the second year of life. In this animals, however, the total amount of mRNA is about half of that of homozygous wild type animals. Different hypotheses could be proposed to explain this phenomenon. First of all, it could be the result of a decrement of NMD mechanism efficiency with neuronal development [25] and possibly with aging, as already observed in other cellular components of protein quality control such as ubiquitin-proteasome system or autophagic pathways $[26,27]$. On the other hand, we cannot exclude that the mutant mRNA and/or protein are more stable and the mRNA portion escaping NMD undergoes accumulation [28]. In any case, NMD decline is observed well after the disease onset.

The age dependent trend in the expression of cacna1 $a^{\text {tg-la }}$ could also explain the conflicting results of previous measurements of cacna1a ${ }^{\text {tg-la }}$ mRNA and protein by immunocytochemistry, in situ hybridization and northern-blot analysis. In fact, no difference between leaner and wild type mice was reported in some studies [29], while in others a very marked decrease or even the complete lack of mutant mRNA was observed [30].

All these data were obtained in mice showing an ataxic phenotype firstly described as recessive, while in humans mutations at the orthologous gene produce an autosomal dominant disorder. However, heterozygotes for both leaner and knockout mutations were recently shown to have a clear deficit in motor learning and in the vestibuloocular reflex [31], thus revealing a dominant effect of these mutations. In addition, in heterozygous leaner mutant mice also a reduced $\mathrm{Ca}_{\mathrm{v}}$ 2.1-mediated acetylcholine release at their neuromuscular junctions [32] and age-dependent motor and cognitive deficits [33] have been observed. The disease progression comparison of EA2 and the leaner phenotype strengthens even more the similarity between human and murine diseases. Although no longitudinal studies have been published, at our knowledge, on the natural history of the disease, EA2 is usually described as a non progressive disorder in contrast with the allelic disease SCA6, characterized by a progressive ataxia [34]. In our experience EA2 clinical picture is extremely variable over time: either decreasing or increasing its severity, but mostly being stable with age. This makes the leaner mice with their non progressive disorder a good animal model for studying the molecular mechanism underlying dominant inheritance of EA2 in man.

The finding that a mechanism degrading PTC-containing mRNAs, such as NMD, might have an effect on the cacna1 a gene has implications for the pathogenic mechanism of human EA2 mutations of the same type. A dominant negative effect of EA2 mutant Cav2.1 $\alpha$-subunit on normal protein has been demonstrated by double transfection methods for mutations producing PTCs as well [6,11-14]. However, the present results on leaner mice and the similar phenotype of cacna1a null, 
knockout and knockdown mice [20-22] would indicate that also a haploinsufficiency mechanism can cause ataxia.

For this reason, a haploinsufficiency mechanism could be supposed in EA2 patients carrying CACNA1A mutations leading to PTCs (that account for $>60 \%$ of the total mutations), especially with early stop codon like those recently described in the first protein domain [10]. These latter cases are particularly significant because the truncating mutations involve the protein $\mathrm{N}$-terminus, where the dominant negative effect over the wild type protein was shown [35].

The quality control mechanism degrading $\mathrm{Ca}_{\mathrm{v}} 2.1 \mathrm{mRNA}$ carrying a PTC, however, appears to be age dependent. It may be possible that a haploinsufficiency mechanism in youngsters might be gradually substituted by a dominant negative effect in adulthood.

In conclusion, since in humans, as in mice, beyond a dominant negative effect, a mechanism of haploinsufficiency causing ataxia can be supposed in those patients carrying protein mutations producing PTCs, it is necessary to clear up the pathophysiological mechanism for each specific mutation, or class of mutations. This is because dominant negative effect and haploinsufficiency mechanisms work in opposite directions. Therefore, in the first case an effective therapy should disable a toxic molecule while in the second it should increase the expression of that particular product.

\section{Acknowledgements}

The research was supported by Italian Ministry of the UniversityProgetti di Ricerca di Interesse Nazionale 2007, contract grant no. 20078RWJBN_002 to CJ. The authors thank Prof. Andrea Novelletto for his invaluable advice.

\section{References}

[1] Volsen SG, Day NC, McCormack AL, Smith W, Craig PJ, Beattie R, et al. The expression of neuronal voltage-dependent calcium channels in human cerebellum. Brain Res Mol Brain Res 1995;34:271-82.

[2] Westenbroek RE, Sakurai T, Elliott EM, Hell JW, Starr TV, Snutch TP, et al. Immunochemical identification and subcellular distribution of the alpha $1 \mathrm{~A}$ subunits of brain calcium channels. J Neurosci 1995;15:6403-18

[3] Ophoff RA, Terwindt GM, Vergouwe MN, van Eijk R, Oefner PJ, Hoffman SM, et al. Familial hemiplegic migraine and episodic ataxia type-2 are caused by mutation in the Ca2 + channel gene CACNL1A4. Cell 1996;87:543-52.

[4] Guida S, Trettel F, Pagnutti S, Mantuano E, Tottene A, Veneziano L, et al. Complete loss of $\mathrm{P} / \mathrm{Q}$ calcium channel activity caused by a CACNA1A missense mutation carried by patients with episodic ataxia type 2. Am J Hum Genet 2001;68:759-64.

[5] Jen J, Wan J, Graves M, Yu H, Mock AF, Coulin CJ, et al. Loss-of-function EA2 mutations are associated with impaired neuromuscular transmission. Neurology 2001;57:1843-8.

[6] Jouvenceau A, Eunson LH, Spauschus A, Ramesh V, Zuberi SM, Kullmann DM, et al. Human epilepsy associated with dysfunction of the brain P/Q-type calcium channel. Lancet 2001;358:801-7.

[7] Wappl E, Koschak A, Poteser M, Sinnegger MJ, Walter D, Eberhart A, et al. Functional consequences of $\mathrm{P} / \mathrm{Q}$-type $\mathrm{Ca} 2+$ channel Cav2.1 missense mutation associated with episodic ataxia type 2 and progressive ataxia. J Biol Chem 2002;277:6960-6

[8] Mantuano E, Veneziano L, Spadaro M, Giunti P, Guida S, Leggio MG, et al. Clusters of non-truncating mutations of $\mathrm{P} / \mathrm{Q}$ type $\mathrm{Ca} 2+$ channel subunit $\mathrm{Ca}(\mathrm{v}) 2.1$ causing episodic ataxia 2. J Med Genet 2004:41:e82.

[9] Jen J, Kim GW, Baloh RW. Clinical spectrum of episodic ataxia type 2. Neurology 2004;62:17-22.

[10] Mantuano E, Romano S, Veneziano L, Gellera C, Castellotti B, Caimi S, et al Identification of novel and recurrent CACNA1A gene mutations in fifteen patients with episodic ataxia type 2. J Neurol Sci 2010;291:30-6.
[11] Page KM, Heblich F, Davies A, Butcher AJ, Leroy J, Bertaso F, et al. Dominantnegative calcium channel suppression by truncated constructs involves a kinase implicated in the unfolded protein response. J Neurosci 2004;24:5400-9.

[12] Jeng CJ, Chen YT, Chen YW, Tang CY. Dominant-negative effects of human P/Qtype $\mathrm{Ca} 2+$ channel mutations associated with episodic ataxia type 2 . Am J Physiol Cell Physiol 2006;290:C1209-20.

[13] Raike RS, Kordasiewicz HB, Thompson RM, Gomez CM. Dominant-negative suppression of Cav2.1 currents by alpha(1)2.1 truncations requires the conserved interaction domain for beta subunits. Mol Cell Neurosci 2007;34:168-77.

[14] Mezghrani A, Monteil A, Watschinger K, Sinnegger-Brauns MJ, Barrere C, Bourinet $\mathrm{E}$, et al. A destructive interaction mechanism accounts for dominant-negative effects of misfolded mutants of voltage-gated calcium channels. J Neurosci 2008;28:4501-11.

[15] Fletcher CF, Lutz CM, O'Sullivan TN, Shaughnessy Jr JD, Hawkes R, Frankel WN et al. Absence epilepsy in tottering mutant mice is associated with calcium channel defects. Cell 1996;87:607-17.

[16] Mori Y, Wakamori M, Oda S, Fletcher CF, Sekiguchi N, Mori E, et al. Reduced voltage sensitivity of activation of P/Q-type $\mathrm{Ca} 2+$ channels is associated with the ataxic mouse mutation rolling Nagoya (tg(rol)). J Neurosci 2000;20:5654-62.

[17] Xie G, Clapcote SJ, Nieman BJ, Tallerico T, Huang Y, Vukobradovic I, et al. Forward genetic screen of mouse reveals dominant missense mutation in the P/Q-type voltage-dependent calcium channel, CACNA1A. Genes Brain Behav 2007;6: 717-27.

[18] Holbrook JA, Neu-Yilik G, Hentze MW, Kulozik AE. Nonsense-mediated decay approaches the clinic. Nat Genet 2004;36:801-8.

[19] Rebbapragada I, Lykke-Andersen J. Execution of nonsense-mediated mRNA decay: what defines a substrate? Curr Opin Cell Biol 2009;21:394-402.

[20] Jun K, Piedras-Renteria ES, Smith SM, Wheeler DB, Lee SB, Lee TG, et al. Ablation of $\mathrm{P} / \mathrm{Q}$-type $\mathrm{Ca}(2+)$ channel currents, altered synaptic transmission, and progressive ataxia in mice lacking the alpha(1A)-subunit. Proc Natl Acad Sci USA 1999:96: 15245-50.

[21] Fletcher CF, Tottene A, Lennon VA, Wilson SM, Dubel SJ, Paylor R, et al. Dystonia and cerebellar atrophy in Cacna1a null mice lacking P/Q calcium channel activity. FASEB J 2001:15:1288-90.

[22] Saito H, Okada M, Miki T, Wakamori M, Futatsugi A, Mori Y, et al. Knockdown of Cav2.1 calcium channels is sufficient to induce neurological disorders observed in natural occurring Cacna1a mutants in mice. Biochem Biophys Res Commun 2009;390:1029-33.

[23] Van Valen P. Oligosyndactylism, an early embryonic lethal in the mouse. J Embryol Exp Morphol 1966;15:119-24.

[24] Livak KJ, Schmittgen TD. Analysis of relative gene expression data using real-time quantitative PCR and the 2(-Delta Delta C(T)) Method. Methods 2001;25:402-8.

[25] Linde L, Boelz S, Nissim-Rafinia M, Oren YS, Wilschanski M, Yaacov Y, et al. Nonsense-mediated mRNA decay affects nonsense transcript levels and governs response of cystic fibrosis patients to gentamicin. J Clin Invest 2007;117:683-92.

[26] Carrard G, Bulteau AL, Petropoulos I, Friguet B. Impairment of proteasome structure and function in aging. Int J Biochem Cell Biol 2002;34:1461-74.

[27] Levine B, Klionsky DJ. Development by self-digestion: molecular mechanisms and biological functions of autophagy. Dev Cell 2004;6:463-77.

[28] Perrin-Vidoz L, Sinilnikova OM, Stoppa-Lyonnet D, Lenoir GM, Mazoyer S. The nonsense-mediated mRNA decay pathway triggers degradation of most BRCA1 mRNAs bearing premature termination codons. Hum Mol Genet 2002;11: 2805-14

[29] Lau FC, Abbott LC, Rhyu IJ, Kim DS, Chin H. Expression of calcium channel alpha1A mRNA and protein in the leaner mouse (tgla/tgla) cerebellum. Brain Res Mol Brain Res 1998;59:93-9.

[30] Doyle J, Ren X, Lennon G, Stubbs L. Mutations in the Cacnl1a4 calcium channel gene are associated with seizures, cerebellar degeneration, and ataxia in tottering and leaner mutant mice. Mamm Genome 1997;8:113-20.

[31] Katoh A, Jindal JA, Raymond JL. Motor deficits in homozygous and heterozygous p/q-type calcium channel mutants. J Neurophysiol 2007;97:1280-7.

[32] Kaja S, Van De Ven RC, Frants RR, Ferrari MD, Van Den Maagdenberg AM, Plomp JJ. Reduced ACh release at neuromuscular synapses of heterozygous leaner $\mathrm{Ca}(\mathrm{v}) 2.1$ mutant mice. Synapse 2008;62:337-44.

[33] Alonso I, Marques JM, Sousa N, Sequeiros J, Olsson IA, Silveira I. Motor and cognitive deficits in the heterozygous leaner mouse, a Cav2.1 voltage-gated Ca2+ channel mutant. Neurobiol Aging 2008;29:1733-43.

[34] Rajakulendran S, Schorge S, Kullmann DM, Hanna MG. Dysfunction of the Ca(V)2.1 calcium channel in cerebellar ataxias. Biol Rep 2010;2 F1000.

[35] Page KM, Heblich F, Margas W, Pratt WS, Nieto-Rostro M, Chaggar K, et al. N terminus is key to the dominant negative suppression of $\mathrm{Ca}(\mathrm{V}) 2$ calcium channels: implications for episodic ataxia type 2. J Biol Chem 2010;285:835-44. 